Research Article

\title{
Determination of the Levels of Heavy Metals and Formaldehyde in Baby Clothes in South Africa: A Case Study of Stores in the Greater Cape Town Region
}

\author{
P. Nyamukamba ${ }^{D}$, C. Bantom, Z. Mququ, T. Ngcobo, and S. Isaacs \\ Technology Station: Clothing and Textiles, Cape Peninsula University of Technology, Symphony Way, Bellville, \\ Cape Town 7535, South Africa \\ Correspondence should be addressed to P. Nyamukamba; nyamukambap@cput.ac.za
}

Received 22 November 2019; Revised 24 January 2020; Accepted 4 February 2020; Published 28 February 2020

Academic Editor: Jose M. Pedrosa

Copyright (C) 2020 P. Nyamukamba et al. This is an open access article distributed under the Creative Commons Attribution License, which permits unrestricted use, distribution, and reproduction in any medium, provided the original work is properly cited.

Herein, we report on the determination of formaldehyde, $\mathrm{pH}$, and heavy metals $(\mathrm{Pb}, \mathrm{As}, \mathrm{Co}, \mathrm{Cr}, \mathrm{Ni}$, and $\mathrm{Cd})$ in various baby apparel (cotton, polyester, nylon, elastane, and polyethylene) of different colours (light, medium, and dark) purchased from both high-end and low-end market stores. The concentrations of the heavy metals were determined by inductively coupled plasma (ICP) after wet digestion and also after extraction using artificial sweat for a selected range of skin-contact baby apparel. The relative standard deviation for the determination of all heavy metals was less than 5\% except for nickel which was $10.49 \%$. The concentrations of the heavy metals in wet digested samples were found to be in the following range: $\mathrm{Pb}(0.02-23.662 \mathrm{mg} / \mathrm{kg}), \mathrm{As}$ (0.009-0.033 mg/kg), Co (0.001-1.053 mg/kg), Cr (0.053-6.373 mg/kg), Ni (0.039-36.715 mg/kg), and Cd (0.001-0.914 mg/kg), whereas the concentrations in artificial sweat extracted samples were in the following range: $\mathrm{Pb}(0.006-1.658 \mathrm{mg} / \mathrm{kg}), \mathrm{As}(\mathrm{not}$ detected), Co $(0.001-1.05 \mathrm{mg} / \mathrm{kg}), \mathrm{Cr}(0.112-0.371 \mathrm{mg} / \mathrm{kg}), \mathrm{Ni}(0.062-0.121 \mathrm{mg} / \mathrm{kg})$, and Cd $(0.001-0.018 \mathrm{mg} / \mathrm{kg})$. The highest concentrations of $\mathrm{Pb}, \mathrm{Cr}$, and $\mathrm{Co}$ after wet digestion were found in baby apparel purchased from low-end market stores, whereas for $\mathrm{As}, \mathrm{Ni}$, and $\mathrm{Cd}$ were from high-end market stores. All the samples had a formaldehyde concentration within the acceptable limits recommended by Oeko-Tex. Out of the thirty-four samples analysed, fifteen samples were found to have a $\mathrm{pH}$ higher than Oeko-Tex limits. The $\mathrm{pH}$ values for the samples that exceeded the Oeko-Tex limits were in the alkali region, and the highest was 11.31 which exceeded by 3.81 .

\section{Introduction}

Textiles are always in contact with the human skin through wearable clothing, cleansing apparel, carpeting, furniture cover, and bedding just to mention a few. It is therefore paramount that these textiles and apparel do not pose a health risk to both humans and animals and cause environmental harm in case of exposure. Despite these concerns, a lot of chemicals and heavy metals are being used in the textile manufacturing processes, for instance, the dying process using azo dyes and metal complex dyes [1].

Azo dyes are the most commonly used group of dyes in the textile industry, and they were reported to constitute between 60 and $70 \%$ of all dyestuffs concerning textile production $[2,3]$. The chemical pollutants present in textiles are mainly dyes containing carcinogenic amines, metals, chlorine bleaching, fire retardants, halogen carriers, free formaldehyde, biocides, pentachlorophenol, and softeners [4]. It was reported that aromatic amines can be released by azo dyes through bacterial biotransformation and their exposure from consumer products bear risks for human health, particularly associated to mutagenic and carcinogenic properties of certain AAs [2].

Product safety regulations are becoming stricter; hence, more testing of toxic substances such as formaldehyde and heavy metals at lower levels is required especially in children's toys and apparel because children tend to put these items in their mouths. Formaldehyde is used to increase 
wrinkle and crease resistance in textiles, and it also helps some dyes and inks to better penetrate fabrics. The raw materials used in the manufacturing of synthetic dyes should not contain compounds known to pose health risks. Formaldehyde is toxic, allergenic, and carcinogenic and can cause symptoms like headaches, burning sensation in the throat, and difficulty breathing [5]. Long-term exposure to formaldehyde can lead to cancer.

Heavy metals are also found in textile products, and their presence is partly attributed to the use of dyes especially the reactive dyes because they contain traces of heavy metals at high level. Heavy metals may pose some health risks to humans even at low concentrations in textile products since they can reach the human body through skin-contact clothes. High levels of heavy metals in textiles may also result in high metal levels in wastewater, and this has a negative impact on the environment, water quality, and microorganisms. It has been reported that the presence of some metals, for instance, in cotton leads to problems in the manufacturing, dyeing, and processing quality [6]. The continued exposure to low levels of toxic elements such as mercury $(\mathrm{Hg})$, cadmium $(\mathrm{Cd})$, arsenic $(\mathrm{As})$, and lead $(\mathrm{Pb})$ has been associated with a number of adverse effects [4, 7]. In South Africa, studies on toxic substances in clothing products are very limited; hence, this study was undertaken for the safety of consumers and also the textile industry itself.

This study aims at investigating the levels of heavy metals and selected organic contaminants in baby apparel as they (babies) are the most affected to check if they fall within the Oeko-Tex Standard 100 limits which prohibits use of some chemical substances that are dangerous to humans [10]. Among the parameters that are controlled by Oeko-Tex, the $\mathrm{pH}$, formaldehyde concentration, and extractable heavy metals were studied.

\section{Experimental}

\subsection{Materials}

2.1.1. Determination of $p H$. Textile processes involve the use of strong acids or alkalis which may cause irritation to skin when in contact. The $\mathrm{pH}$ was determined using a method developed by the International Organization for Standardization (ISO 3071:2005). About $2.0 \mathrm{~g}$ of the apparel samples was cut into small pieces having approximately $2 \mathrm{~cm} \times 2 \mathrm{~cm}$ so that the test samples could be effectively wet. The handling of the samples was minimal to avoid contamination. The cut samples were put in a $250 \mathrm{~mL}$ volumetric flask containing $100 \mathrm{~mL}$ of water whose $\mathrm{pH}$ and temperature was $7.5^{\circ} \mathrm{C}$ and $27^{\circ} \mathrm{C}$, respectively, and agitated to ensure that all the fabric was wet. After 2 hrs of shaking, the first extract was decanted into a $50 \mathrm{~mL}$ beaker and stirred with a $\mathrm{pH}$ electrode. The second and third extracts were decanted in separate beakers, and the $\mathrm{pH}$ values were measured immediately.

\subsection{Determination of Heavy Metals by Extraction}

2.2.1. Extraction Using Artificial Sweat Solution. The artificial sweat solution was prepared using the standard procedure reported in ISO 3160/2. In a typical experiment, about $20 \mathrm{~g} \mathrm{NaCl}, 17.5 \mathrm{~g} \mathrm{NH}_{4} \mathrm{Cl}, 5 \mathrm{~g} \mathrm{CH}_{3} \mathrm{COOH}$, and $15 \mathrm{~g}$ lactic acid were dissolved in a litre of deionized water and the $\mathrm{pH}$ was adjusted to 4.7 using sodium hydroxide solution. About $2.0 \mathrm{~g}$ of the cut apparel sample was mixed with $50 \mathrm{~mL}$ of artificial sweat solution, shaken for $24 \mathrm{hrs}$ and then filtered. The filtrate was then analysed by ICP.

2.2.2. ICP Analysis. ICP was used to determine the concentration of the heavy metals in the extracted samples. It was done using a Spectro Arcos ICP-OES instrument equipped with a side-on plasma interface. Sample inlet was done using a four-channel peristaltic pump which provides a segmented flow of the liquid samples. A $10 \%$ solution of nitric acid was used for washing between sample analyses, i.e., before the next sample could be analysed. Prior to analysis, the ICP-OES measurement conditions were optimized and the following conditions were used: plasma power, $1400 \mathrm{~W}$; pump speed, $30 \mathrm{rpm}$; coolant flow, $14.00 \mathrm{~L} / \mathrm{min}$; auxiliary flow, $2.10 \mathrm{~L} / \mathrm{min}$; and nebulizer flow, $0.80 \mathrm{~L} / \mathrm{min}$.

2.2.3. Determination of Heavy Metals by Digestion. A modified version of the method by Sungur and Gulmez [9], was used to determine the concentration of heavy metals by wet digestion. In a typical experiment, about $2.0 \mathrm{~g}$ of apparel sample was heated at $110^{\circ} \mathrm{C}$ for an hour in $20 \mathrm{~mL}$ of $1: 5$ $\mathrm{H}_{2} \mathrm{O}_{2}(30 \%) / \mathrm{HNO}_{3}(70 \%)$ acid mixture. The resulting solutions were cooled and filtered. After filtration, the solutions were filled up to $50 \mathrm{~mL}$ with deionized water and analysed by ICP.

2.3. Determination of Formaldehyde. Formaldehyde concentration was determined using the method described in ISO 14184-1. The apparel purchased from low-end and highend market stores were clearly identified, separated, coded, and then cut into small pieces, and about $2.5 \mathrm{~g}$ of each test specimen was then put in $100 \mathrm{~mL}$ of distilled water in a $250 \mathrm{~mL}$ volumetric flask. This was then shaken and heated at $40^{\circ} \mathrm{C}$ for an hour, and the resulting solutions were filtered. About $5 \mathrm{~mL}$ of each filtered solution was mixed with $5 \mathrm{~mL}$ of acetylacetone in a tube, and the same was done with standard formaldehyde solution. The tubes were put in water that was set at a temperature of about $40^{\circ} \mathrm{C}$ for an hour and then at room temperature for 30 minutes. The blank was prepared by adding acetylacetone to water and treating it the same way. The absorbances were then measured in triplicates at a wavelength of $412 \mathrm{~nm}$ using a UV-Vis spectrophotometer.

2.3.1. Preparation of a Standard Solution. About $1500 \mu \mathrm{g} /$ $\mathrm{mL}$ stock solution was prepared by diluting $0.95 \mathrm{~mL}$ of $37 \%$ (m/V) formaldehyde solution with $250 \mathrm{~mL}$ of distilled water. Using the stock solution, $75 \mu \mathrm{g} / \mathrm{ml}$ of formaldehyde solution was prepared which was then used to prepare calibration solutions. The concentrations of the calibration solutions prepared were $0.15 \mu \mathrm{g} / \mathrm{mL}, \quad 0.30 \mu \mathrm{g} / \mathrm{mL}, \quad 0.75 \mu \mathrm{g} / \mathrm{mL}$, $1.50 \mu \mathrm{g} / \mathrm{mL}$, and $3.00 \mu \mathrm{g} / \mathrm{mL}$. 
The sample codes, description, composition, colour, and fabric type of baby apparel purchased from high-end and low-end market stores are presented in Tables 1 and 2, respectively. The various clothing fabric were made of cotton, polyester, nylon, elastane, and polyethylene, the most common being $100 \%$ cotton. The apparel type consisted of woven print, knitted print, woven pile, weft knit, woven piledyed, terry knit, weft knitted-dyed, and knitted. The range of samples included jeans, socks, cap, receiving blankets, vests, towels, bibs, and growers.

\section{Results and Discussion}

It is important to control the $\mathrm{pH}$ of baby apparel which is in direct contact with the skin so as to prevent irritation and itchiness to the skin. In this study, it was found that more than $50 \%$ of the apparel from both high-end and low-end market stores was within the recommended $\mathrm{pH}$ level range as shown in Table 3. Out of the seventeen samples from high-end market stores, $47.06 \%$ had a $\mathrm{pH}$ above the recommended range, whereas $41.18 \%$ of the seventeen samples from low-end market stores had a $\mathrm{pH}$ above the recommended range. Sample L10 from the lowend market store had the highest $\mathrm{pH}$ deviation of 3.81, and it was made of $100 \%$ cotton. Generally, all the samples which were not in the recommended range were in the alkaline region and none was in the acidic region. Those fabrics which are not in the recommended range might cause contact dermatitis due to their alkali nature because a natural human skin surface $\mathrm{pH}$ is on average below 5 , which is beneficial for its resident flora. It has been reported that changes in the skin $\mathrm{pH}$ play a role in the development of skin diseases such as irritant contact dermatitis, acne vulgaris, atopic dermatitis, ichthyosis, and Candida albicans infections [10]; hence, fabric $\mathrm{pH}$ control is necessary. Teijin Fibers Limited in 2011 announced that they developed a new polyester fabric that can maintain the skin's mild acidic $\mathrm{pH}$ level, similar to healthy skin. To the best of our knowledge, no study has been done on the determination of $\mathrm{pH}$ on baby clothes in South Africa even though we believe that it is an important parameter to be measured.

The apparel purchased from both high-end and lowend market shops were tested for formaldehyde concentration, and the results found are shown in Table 4. All the apparel had formaldehyde concentrations within the Oeko-Tex limits implying that they do not pose a health harm to humans due to formaldehyde. In another study, Novick et al. [11] analyzed twenty clothing items to detect the levels of formaldehyde, and they found it in only three items of which two of them had levels higher than the concentrations established by international textile regulations. Contact of the skin with formaldehyde may cause primary irritation or allergic dermatitis. According to the International Agency for Research on Cancer (IARC), formaldehyde is classified as carcinogenic to humans (Group 1) [12]. The other effects of formaldehyde include irritation of the mucous membrane, immediate, anaphylactic reactions (Type I allergy), upper respiratory tract irritation, neurophysiologic effect, and ocular irritation $[13,14]$.

The concentrations of the heavy metals after wet digestion in the garments purchased from high-end and low-end market stores are shown in Tables 5 and 6, respectively. The concentrations of the heavy metals were found to be in the following range: $\mathrm{Pb}(0.02-23.662 \mathrm{mg} / \mathrm{kg})$, As $(0.009-0.033 \mathrm{mg} /$ $\mathrm{kg})$, Co $(0.001-1.053 \mathrm{mg} / \mathrm{kg})$, Cr $(0.053-6.373 \mathrm{mg} / \mathrm{kg})$, Ni $(0.039-36.715 \mathrm{mg} / \mathrm{kg})$, and Cd $(0.001-0.914 \mathrm{mg} / \mathrm{kg})$. The toxic effects of heavy metals on humans are well documented, and the maximum permissible values for metals in textiles are given by different regulations; in this study, comparison will be made to Oeko-Tex standards. The only elements whose limits are given by the Oeko-Tex Standard 100 regarding wet digestion extraction are $\mathrm{Pb}(<90)$ and $\mathrm{Cd}(<40)$, but as for artificial sweat extraction, all elements studied have Oeko-Tex Standard limits.

Both $\mathrm{Pb}$ and $\mathrm{Cd}$ concentrations in the baby apparel were below the recommended limits by Oeko-Tex meaning that the baby apparel under study will not pose a health risk due to $\mathrm{Pb}$ or $\mathrm{Cd}$. The highest concentrations of $\mathrm{Pb}(23.662 \mathrm{mg} /$ $\mathrm{kg})$, Co $(1.053 \mathrm{mg} / \mathrm{kg})$, and $\mathrm{Cr}(6.373 \mathrm{mg} / \mathrm{kg})$ were found in apparel purchased from low-end market stores, whereas the highest concentrations of As $(0.033 \mathrm{mg} / \mathrm{kg}), \mathrm{Ni}(36.715 \mathrm{mg} /$ $\mathrm{kg})$, and $\mathrm{Cd}(0.914 \mathrm{mg} / \mathrm{kg})$ were found in apparel from highend market stores. Arsenic had the least concentration in most fabrics from both high-end and low-end market stores. The abundance of metal concentrations follows the order: $\mathrm{Ni}>\mathrm{Pb}>\mathrm{Cr}>\mathrm{Cd}>\mathrm{Co}>\mathrm{As}$ for high-end market apparel and $\mathrm{Ni}>\mathrm{Pb}>\mathrm{Cr}>\mathrm{Co}>\mathrm{Cd}>\mathrm{As}$ for low-end market stores. In almost all fabrics, nickel was the most abundant element. Although nickel is an essential trace element for human and animal health, large quantities of nickel in the body can result in birth defects, asthma, respiratory failure, and chronic bronchitis. It can also cause cancer on different sites within the bodies of animals [15]. High Ni concentrations and long-term exposure to humans can lead to liver, heart damage, and skin irritation as reported in the literature [16].

Sample T7 which was a blue-dyed facecloth made of 100\% cotton had the least amounts of most elements, i.e., $\mathrm{Pb}, \mathrm{Co}, \mathrm{Cr}$, and Ni. On the contrary, T9, a white vest made of $100 \%$ cotton had the highest concentrations of all the detected elements $(\mathrm{Pb}$, $\mathrm{Cr}, \mathrm{Ni}$, and $\mathrm{Cd}$ ) implying that this is the worst apparel among all the sample apparel from the high-end market stores. The chromium that was found in the apparel may originate from the dye which did not fully get incorporated into the fibre, and this chromium may affect babies during perspiration. This skin exposure can be a dangerous route of absorption, promoting dermatitis [17]. Chromium (VI) is used in certain textile processes, and it is highly toxic even at low concentrations. High levels of $\mathrm{Cr}$ have been reported to cause a reduction in the percentage of body fat, resulting into weight loss in humans [18]. There are some clinical and laboratory evidences which indicate that hexavalent chromium, $\mathrm{Cr}(\mathrm{VI})$, is responsible for most of the toxic actions [19]. 
TABle 1: Sample code, description, colour, composition, and apparel type from a high-end market store.

\begin{tabular}{|c|c|c|c|c|c|c|}
\hline Code & Description & Colour & Dye/print & Made in & Composition & Woven/knit \\
\hline $\mathrm{T} 1$ & Blanket & White & Print & SA & $100 \%$ Cot & Woven \\
\hline $\mathrm{T} 2$ & Blanket & Navy & Print & SA & $100 \%$ Cot & Woven \\
\hline T3 & Blanket & Blue/navy & Print & NS & $100 \% \mathrm{PET}$ & Knit \\
\hline $\mathrm{T} 4$ & Fleece & White & - & China & $100 \%$ PET & Knit \\
\hline T5 & Nappy & White & - & SA & $100 \%$ Cot & Woven-pile \\
\hline T6 & Towel & Blue & Dye & China & $100 \%$ Cot & Woven-pile \\
\hline T7 & Facecloth & Blue & Dye & China & $100 \%$ Cot & Woven-pile \\
\hline T8 & Facecloth & White & - & SA & $100 \%$ Cot & Woven-pile \\
\hline T9 & Vest & White & - & SA & $100 \%$ Cot & Knit \\
\hline $\mathrm{T} 10$ & Cap & White & - & SA & $100 \%$ Cot & Knit \\
\hline T11 & Cap & Blue & Dye & SA & $100 \% \operatorname{Cot}$ & Knit \\
\hline $\mathrm{T} 12$ & Socks & White & - & China & $80 \%$ Cot, $18 \%$ PA, $2 \%$ EL & Knit-terry \\
\hline $\mathrm{T} 13$ & Socks & Blue & Dye & SA & $80 \%$ Cot, $18 \%$ PA, $2 \%$ EL & Knit-terry \\
\hline $\mathrm{T} 14$ & Grower & White & - & NS & $100 \% \operatorname{Cot}$ & Knit \\
\hline $\mathrm{T} 15$ & Grower & Yellow & Dye & SA & $100 \%$ Cot & Knit \\
\hline $\mathrm{T} 16$ & Grower & Navy blue & Dye & China & $100 \% \operatorname{Cot}$ & Knit \\
\hline $\mathrm{T} 17$ & Jeans & Navy blue & Dye & Bangladesh & $75 \%$ Cot, $23 \%$ PET, $2 \%$ EL & Woven \\
\hline
\end{tabular}

Cot: Cotton; PA: Nylon; PET: Polyester; EL: Elastane, SA: South Africa, NS: not specified.

TABLe 2: Sample code, description, composition and apparel type from a low end market store.

\begin{tabular}{|c|c|c|c|c|c|}
\hline Code & Description & Colour & Made in & Composition & Fabric type \\
\hline L1 & Face towel & White & Pakistan & $100 \%$ Cot & Woven pile \\
\hline $\mathrm{L} 2$ & Facecloth & Blue & Pakistan & $100 \% \operatorname{Cot}$ & Woven pile \\
\hline L3 & $\mathrm{Bib}$ & Blue \& white & & $100 \% \operatorname{Cot}$ & Knitted \\
\hline L4 & $\mathrm{Bib}$ & White \& powder blue & China & 98\% PET, $2 \%$ PE & Knitted \\
\hline L5 & $\mathrm{Bib}$ & White \& sky blue & China & $98 \%$ PET, $2 \%$ PE & Knitted \\
\hline L6 & Nappy & White & & $100 \%$ Cot & Woven pile \\
\hline L7 & Bath towel & Powder blue & Pakistan & $100 \% \operatorname{Cot}$ & Woven pile \\
\hline L8 & Blanket & White & SA & $100 \% \mathrm{PET}$ & Woven pile \\
\hline L9 & Blanket & Brown & China & $100 \% \mathrm{PET}$ & Woven \\
\hline L10 & Receiver & White & Pakistan & $100 \% \operatorname{Cot}$ & Woven print \\
\hline L11 & Grower & White & SA & $100 \% \operatorname{Cot}$ & Woven pile \\
\hline L12 & Grower & White & China & $100 \% \operatorname{Cot}$ & Woven \\
\hline L13 & Grower & Yellow & & $100 \% \operatorname{Cot}$ & Woven \\
\hline L14 & Romper & Navy & China & $100 \% \mathrm{PET}$ & Woven pile \\
\hline L15 & Socks & White & SA & 93\% PET, 5\% EL, 2\% PA & Knitted \\
\hline L16 & Socks & Blue & NS & 93\% PET, 5\% EL, 2\% PA & Knitted \\
\hline L17 & Jean & Navy & SA & $73 \%$ Cot, $25 \%$ PET, $2 \%$ EL & Woven \\
\hline
\end{tabular}

Cot: cotton; PA: nylon; PET: polyester; PE: polyethylene; EL: elastane.

Clothes that are in direct contact with the skin are usually exposed to perspiration, which may cause metal extraction from textiles and absorption to skin [17]. Sport activities such as marathon would be of special concern when studying clothing for adults, as the sweaty athlete remains in contact with the clothes. The concentrations of heavy metals in all examined textile apparel after extraction using artificial sweat (Table 7) were lower than those for wet digestion. The low leaching rates of heavy metals in artificial sweat extract is an indication of the quality of the textile products. The determination of the amounts of these heavy metals that might pass into the human body from textile products as a result of sweating is very significant.

The concentrations extracted using artificial sweat in selected skin-contact apparel were in the following range: $\mathrm{Pb}$ (0.006-1.658 mg/kg), As (not detected), Co (0.001-1.05 mg/kg),
$\mathrm{Cr}(0.112-0.371 \mathrm{mg} / \mathrm{kg}), \mathrm{Ni}(0.062-0.121 \mathrm{mg} / \mathrm{kg})$, and $\mathrm{Cd}$ $(0.001-0.018 \mathrm{mg} / \mathrm{kg})$, as shown in Table 7 . The levels of the heavy metals followed the order $\mathrm{Pb}>\mathrm{Co}>\mathrm{Cr}>\mathrm{Ni}>\mathrm{Cd}$ which is different from the order found in wet digestion extraction due to the variance in solubility of the heavy metals in different extraction media. T5 and L14 are the only skin-contact samples whose $\mathrm{Pb}$ concentrations were higher than the limits recommended by Oeko-Tex. The concentration range of $\mathrm{Pb}$ in this study was higher than that found by Rovira et al. [4], which were in the range $0.03-0.32 \mathrm{mg} / \mathrm{kg}$ in skin-contact clothing samples. These apparel whose lead concentrations are higher than the limits recommended by Oeko-Tex may pose a health risk to babies who wear them because lead is a neurotoxin, it affects the human brain as well as the reproductive system. There are certain kinds of neurological damage caused by lead that cannot be reversed. 
TABLE 3: $\mathrm{pH}$ of fabrics from store $\mathrm{A}$ and store $\mathrm{B}$ and the Oeko-Tex recommended values.

\begin{tabular}{lcccc}
\hline Sample code & $\mathrm{pH}$ & Sample code & $\mathrm{pH}$ & \\
\hline T1 & 7.71 & L1 & 7.25 & Recommended \\
T2 & 7.42 & L2 & 7.60 & $4.0-7.5$ \\
T3 & 5.46 & L3 & 7.65 & $4.0-7.5$ \\
T4 & 5.56 & L4 & 5.09 & $4.0-7.5$ \\
T5 & L5 & 7.55 & $4.0-7.5$ \\
T6 & 8.34 & L6 & 8.30 & $4.0-7.5$ \\
T7 & 8.49 & L7 & 7.04 & $4.0-7.5$ \\
T8 & 7.63 & L8 & 5.49 & $4.0-7.5$ \\
T9 & 6.19 & L9 & 6.87 & $4.0-7.5$ \\
T10 & 8.89 & L10 & 11.31 & $4.0-7.5$ \\
T11 & 8.35 & L12 & 6.77 & $4.0-7.5$ \\
T12 & 7.66 & L13 & 7.42 & $4.0-7.5$ \\
T13 & L14 & 9.29 & $4.0-7.5$ \\
T14 & L15 & 6.78 & $4.0-7.5$ \\
T15 & 6.79 & L16 & 8.64 & $4.0-7.5$ \\
T16 & 6.25 & L17 & 6.00 & $4.0-7.5$ \\
T17 & 6.86 & & 7.48 & $4.0-7.5$ \\
\hline
\end{tabular}

TABLE 4: Formaldehyde concentration in apparel purchased from high-end and low-end market stores, and the Oeko-Tex recommended values.

\begin{tabular}{lcccc}
\hline Sample & Formaldehyde conc. $(\mathrm{mg} / \mathrm{kg})$ & Sample & Formaldehyde conc. $(\mathrm{mg} / \mathrm{kg})$ & Recommended \\
\hline T1 & 0.090 & L1 & 0.044 & $<16 \mathrm{mg} / \mathrm{kg}$ \\
T2 & 0.047 & L2 & 0.041 & $<16 \mathrm{mg} / \mathrm{kg}$ \\
T3 & 0.037 & L3 & 0.074 & $<16 \mathrm{mg} / \mathrm{kg}$ \\
T4 & 0.036 & L4 & 0.048 & $<16 \mathrm{mg} / \mathrm{kg}$ \\
T5 & 0.058 & L5 & 0.041 & $<16 \mathrm{mg} / \mathrm{kg}$ \\
T6 & 0.040 & L6 & 0.040 & $<16 \mathrm{mg} / \mathrm{kg}$ \\
T7 & 0.040 & L7 & 0.040 & $<16 \mathrm{mg} / \mathrm{kg}$ \\
T8 & 0.049 & L8 & 0.038 & $<16 \mathrm{mg} / \mathrm{kg}$ \\
T9 & 0.049 & L9 & 0.037 & $<16 \mathrm{mg} / \mathrm{kg}$ \\
T10 & 0.044 & L10 & 0.070 & $<16 \mathrm{mg} / \mathrm{kg}$ \\
T11 & 0.042 & L11 & 0.039 & $<16 \mathrm{mg} / \mathrm{kg}$ \\
T12 & L12 & 0.040 & $<16 \mathrm{mg} / \mathrm{kg}$ \\
T13 & 0.041 & L13 & 0.039 & $<16 \mathrm{mg} / \mathrm{kg}$ \\
T14 & L14 & 0.037 & $<16 \mathrm{mg} / \mathrm{kg}$ \\
T15 & 0.041 & L15 & 0.040 & $<16 \mathrm{mg} / \mathrm{kg}$ \\
T16 & 0.042 & L16 & 0.036 & $<16 \mathrm{mg} / \mathrm{kg}$ \\
T17 & 0.045 & L17 & 0.053 & $<16 \mathrm{mg} / \mathrm{kg}$ \\
\hline
\end{tabular}

In children, lead affects reading and reasoning abilities and in some instances, it is linked to hearing loss, speech delay, balance difficulties, violent tendencies, clumsiness, agitation, and/or decreased activity and somnolence [20].

L8 is the only sample that had a cobalt concentration higher than the Oeko-Tex limits, but it exceeded slightly. Cobalt may cause skin problems such as eczema if it leaches from the apparel and gets in contact with skin. Cases of severe hand eczema after using a cobalt-containing gel were reported by Chave and Warin [21], and the eczema disappeared when the product was discontinued. Cobalt is a skin sensitizer which may lead to contact dermatitis either allergic or irritant, and the latter is the most frequent [4].

No elements except Cd were detected in T12 which was made of $80 \%$ cotton, $18 \%$ polyester, and $2 \%$ elastane.
Arsenic was not detected in all samples extracted using artificial sweat. Cobalt was only detected in a few samples. $\mathrm{Cd}$ is the only element that was found in all samples but only at very low concentrations when compared to other elements. $\mathrm{Cr}$ and $\mathrm{Ni}$ are the only elements that were found not to exceed the Oeko-Tex limits in all the samples that were under study. The use of artificial sweat gives an indication of the levels of the heavy metals in baby skincontact clothes although the composition of sweat varies between individuals and also in the same individual, depending on body region, age, season, climate, diet, presence of infection, and activity level [22]. Because the sweat varies between individuals, it also means that the amount of heavy metals that will leach will vary from person to person resulting in different side effects in individuals. 


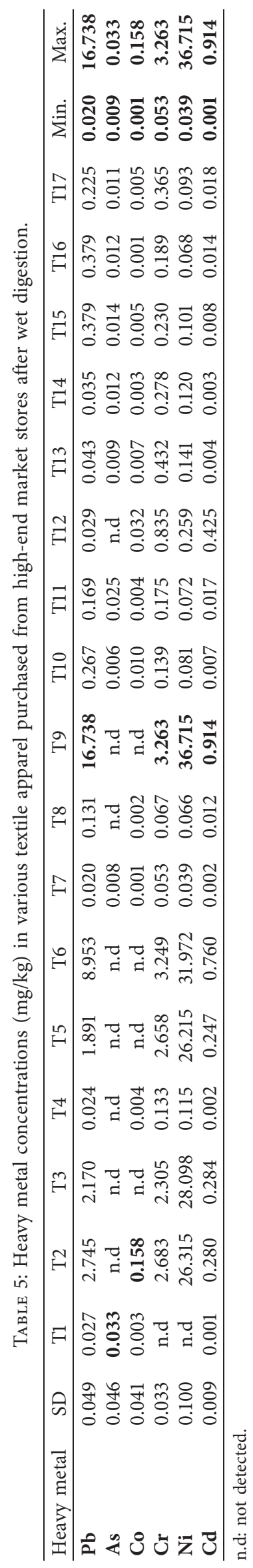




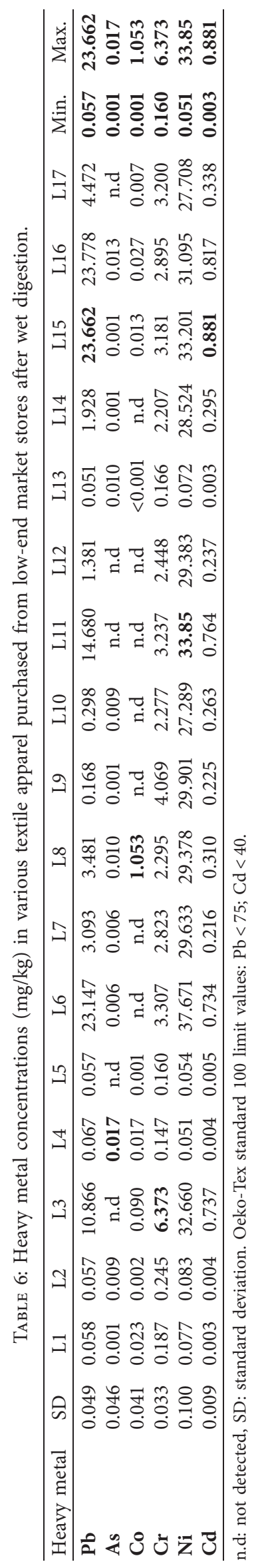


TABLE 7: Heavy metal concentrations $(\mathrm{mg} / \mathrm{kg}$ ) in various textile apparel after extraction with artificial sweat.

\begin{tabular}{lcccccc}
\hline Shop A samples & $\mathrm{Pb}$ & As & Co & $\mathrm{Cr}$ & $\mathrm{Ni}$ & $\mathrm{Cd}$ \\
\hline L3 & 0.075 & n.d & 0.090 & 0.260 & 0.082 & 0.004 \\
L6 & 0.089 & n.d & n.d & 0.165 & 0.062 & 0.006 \\
L7 & 0.056 & n.d & n.d & 0.184 & 0.066 & 0.004 \\
L8 & 0.045 & n.d & 1.05 & 0.262 & 0.121 & 0.004 \\
L9 & 0.167 & n.d & n.d & 0.265 & 0.072 & 0.004 \\
L10 & 0.150 & n.d & n.d & 0.331 & 0.116 & 0.018 \\
L11 & 0.091 & n.d & n.d & 0.195 & 0.092 & 0.005 \\
L12 & 0.022 & n.d & n.d & 0.202 & 0.073 & 0.003 \\
L14 & 1.658 & n.d & n.d & 0.185 & 0.097 & 0.003 \\
L15 & 0.038 & n.d & 0.013 & 0.178 & 0.097 & 0.003 \\
L16 & 0.018 & n.d & 0.004 & 0.182 & 0.082 & 0.023 \\
L17 & 0.047 & n.d & 0.005 & 0.371 & 0.115 & 0.003 \\
T2 & 0.006 & n.d & n.d & n.d & n.d & 0.001 \\
T3 & 0.028 & n.d & n.d & n.d & n.d & 0.001 \\
T5 & 1.492 & n.d & n.d & 0.125 & 0.072 & 0.004 \\
T6 & 0.057 & n.d & n.d & 0.112 & 0.095 & 0.004 \\
T9 & 0.093 & n.d & n.d & 0.140 & 0.102 & 0.005 \\
T12 & n.d & n.d & n.d & n.d & n.d & 0.002 \\
\hline Minimum & 0.006 & - & 0.001 & 0.112 & 0.062 & 0.001 \\
Maximum & 1.658 & - & 1.05 & 0.371 & 0.121 & 0.018 \\
\hline
\end{tabular}

Oeko-Tex standard 100 limit values: $\mathrm{Pb}<0.2 ; \mathrm{As}<0.2 ; \mathrm{Co}<1.0 ; \mathrm{Cr}<1.0$; $\mathrm{Ni}<0.1 ; \mathrm{Cd}<0.1$.

\section{Conclusion}

The determination of the extractable amounts of heavy metals in baby apparel was of great importance because it reflected the possible impact on human health. These days, it is very important to prove that there is little or no formaldehyde in all finished textile materials to avoid posing risks to humans. This study showed that the formaldehyde concentration fall within the Oeko-Tex 100 implying that the garments do not pose a health risk to humans due to the presence of formaldehyde. About $44.12 \%$ of the analysed apparel had a $\mathrm{pH}$ above the recommended range implying that South African textile samples should be analysed more often with respect to $\mathrm{pH}$ before making clothes. The heavy metal concentrations in all baby apparel after extraction using artificial sweat extract were lower than those for wet digestion. Arsenic is the only metal that was not detected in all apparel after extraction using artificial sweat. Only one sample (L8) had a cobalt concentration $(1.05 \mathrm{mg} / \mathrm{kg})$ higher than the Oeko-Tex limits $(1.0 \mathrm{mg} / \mathrm{kg})$, but it exceeded slightly. $\mathrm{Pb}$ concentrations were higher than the limits recommended by Oeko-Tex $(\mathrm{Pb}<0.2 \mathrm{mg} / \mathrm{kg})$ in only two samples $(\mathrm{T} 5=1.492 \mathrm{mg} / \mathrm{kg}$ ) and L14 $(1.658 \mathrm{mg} / \mathrm{kg})$. Cr and $\mathrm{Ni}$ are the only elements that were found not to exceed the Oeko-Tex limits in all the samples that were under study. Generally more samples purchased from low-end market stores had metal concentrations that were higher than the Oeko-Tex limits when compared with the apparel purchased from high-end market stores. The highest concentrations of all the metals detected were found in apparel purchased from low-end market stores. Although the composition of sweat varies between individuals, the results of this study using artificial sweat gave an indication of the levels of the heavy metals in baby skin-contact clothes in Cape Town, South
Africa. The results of this study might be useful to evaluate potential human risk when exposed to heavy metals from textile materials.

\section{Data Availability}

The data used to support the findings of this study are included within the article.

\section{Conflicts of Interest}

The authors declare that they have no conflicts of interest.

\section{Acknowledgments}

The authors acknowledge the financial support from Technology Station: Clothing and Textiles (TSCT) and would like to thank the Environmental and Nanoscience Group (ENS) of the University of the Western Cape (UWC) for the ICP analysis and the Department of Food Science (CPUT) for UV-Vis analysis.

\section{References}

[1] P. I. Dolez and H. Benaddi, Advanced Characterization and Testing of Textiles, Chapter 7 (Toxicity Testing of Textiles), Woodhead Publishing, Sawston, Cambridge, UK, 2018, ISBN: 978-0-08-100453-1.

[2] B. J. Brüschweiler and C. Merlot, "Azo dyes in clothing textiles can be cleaved into a series of mutagenic aromatic amines which are not regulated yet," Regulatory Toxicology and Pharmacology, vol. 88, pp. 214-226, 2017.

[3] D. Rawat, V. Mishra, and R. S. Sharma, "Detoxification of azo dyes in the context of environmental processes," Chemosphere, vol. 155, pp. 591-605, 2016.

[4] J. Rovira, M. Nadal, M. Schuhmacher, and J. L. Domingo, "Human exposure to trace elements through the skin by direct contact with clothing: risk assessment," Environmental Research, vol. 140, pp. 308-316, 2015.

[5] Y. Herschkovitz, I. Eshkenazi, C. E. Campbell, and J. Rishpon, "An electrochemical biosensor for formaldehyde," Journal of Electroanalytical Chemistry, vol. 491, no. 1-2, pp. 182-187, 2000.

[6] M. Zeiner, I. Reziæ, and I. Steffan, "Analytical methods for the determination of heavy metals in the textile industry," Kemija $u$ industriji/Journal of Chemists and Chemical Engineers, vol. 56, no. 11, pp. 587-595, 2007.

[7] A. Roy, K. Kordas, P. Lopez et al., "Association between arsenic exposure and behavior among first-graders from Torreón, Mexico," Environmental Research, vol. 111, no. 5, pp. 670-676, 2011.

[8] C. Tonetti and R. Innocenti, "Determination of heavy metals in textile materials by atomic absorption spectrometry: verification of the test method," AUTEX Research Journal, vol. 9, no. 2, 2009.

[9] Ş. Sungur and F. Gülmez, "Determination of metal contents of various fibers used in textile industry by MP-AES," Journal of Spectroscopy, vol. 2015, p. 5, Article ID 640271, 2015.

[10] M.-H. Schmid-Wendtner and H. C. Korting, "The pH of the skin surface and its impact on the Barrier function," Skin Pharmacology and Physiology, vol. 19, no. 6, pp. 296-302, 2006. 
[11] R. M. Novick, M. L. Nelson, M. A. McKinley, G. L. Anderson, and J. J. Keenan, "The effect of clothing care activities on textile formaldehyde content," Journal of Toxicology and Environmental Health, Part A, vol. 76, no. 14, pp. 883-893, 2013.

[12] International Agency for Research on Cancer (IARC), Chemical Agents and Related Occupations-A Review of Humans Carcinogens, IARC Monographs on the Evaluation of Carcinogenic Risk to Humans, World Human Organization (WHO), Lyon, France, 2012.

[13] M. Inci, I. Zararsiz, M. Davarci, and S. Gorur, "Toxic effects of formaldehyde on the urinary system," Türk Üroloji Dergisi/ Turkish Journal of Urology, vol. 39, no. 1, pp. 48-52, 2013.

[14] M. Lyapina, A. Kisselova-Yaneva, A. Krasteva, M. TzekovaYaneva, and M. Dencheva-Garova, "Allergic contact dermatitis from formaldehyde exposure," Journal of IMAB-Annual Proceeding (Scientific Papers), vol. 18, 2012.

[15] M. Javed and N. Usmani, "Assessment of heavy metal ( $\mathrm{Cu}, \mathrm{Ni}$, $\mathrm{Fe}, \mathrm{Co}, \mathrm{Mn}, \mathrm{Cr}, \mathrm{Zn}$ ) pollution in effluent dominated rivulet water and their effect on glycogen metabolism and histology of Mastacembelus armatus," SpringerPlus, vol. 2, p. 390, 2013.

[16] O. O. James, K. Nwaeze, E. Mesagan, M. Agbojo, K. L. Saka, and D. J. Olabanji, "Concentration of heavy metals in five pharmaceutical effluents in Ogun state, Nigeria," Journal of Environment Pharmacology and Life Sciences, vol. 2, no. 8, pp. 84-90, 2013.

[17] E. Matoso and S. Cadore, "Determination of inorganic contaminants in polyamide textiles used for manufacturing sport T-shirts," Talanta, vol. 88, pp. 496-501, 2012.

[18] M. Peng and X. Yang, "Controlling diabetes by chromium complexes: the role of the ligands," Journal of Inorganic Biochemistry, vol. 146, no. 9, pp. 97-103, 2015.

[19] R. Shrivastava, R. K. Upreti, P. K. Seth, and U. C. Chaturvedi, "Effects of chromium on the immune system," FEMS Immunology \& Medical Microbiology, vol. 34, no. 1, pp. 1-7, 2002.

[20] American Academy of Paediatrics, "Lead exposure in children: prevention, detection and management," Pediatrics, vol. 116, no. 4, pp. 1036-1046, 2005.

[21] T. A. Chave and A. P. Warin, "Allergic contact dermatitis from cobalt in a beauty product," Contact Dermatitis, vol. 41, no. 4, p. 236, 1999.

[22] K. Kulthong, S. Srisung, K. Boonpavanitchakul, W. Kangwansupamonkon, and R. Maniratanachote, "Determination of silver nanoparticle release from antibacterial fabrics into artificial sweat," Particle and Fibre Toxicology, vol. 7, Article ID 8, 2010. 